\title{
Evaluation of bone marrow in female fallow deer kept in captivity
}

\author{
ANNA SNARSKA, ANDRZEJ POMIANOWSKI, PRZEMYSŁAW SOBIECH, \\ SŁAWOMIR GONKOWSKI**, MARCIN LEW*, MAGDALENA DRAZZEK*, \\ KATARZYNA ŻARCZYŃSKA, DOMINIKA WYSOCKA, LILIANA RYTEL, ARTUR STOPYRA
}

\begin{abstract}
Department of Internal Disease, *Department of Surgery and Rentgenology, **Department of Clinical Physiology, Faculty of Veterinary Medicine, University of Warmia and Mazury in Olsztyn, Oczapowskiego St. 14, 10-717 Olsztyn, Poland
\end{abstract}

Snarska A., Pomianowski A., Sobiech P., Gonkowski S., Lew M., Drążek M., Żarczyńska K., Wysocka D., Rytel L., Stopyra A.

Evaluation of bone marrow in female fallow deer kept in captivity

Summary

Proper processes of hematopoiesis have a major impact on the results of blood morphological analyses in healthy animals. The aim of this study was to evaluate bone marrow smears of female fallow deer kept in captivity and comparing them to morphological analysis of peripheral blood. To achieve the aim of this study bone marrow was collected from 10 nonpregnant, 2-year-old female fallow deer. Smears stained by the May-Grünwald Giemsa method were analyzed. Bone marrow samples were collected using a biopsy needle from the $3^{\text {rd }}-4^{\text {th }}$ rib in the sternal region into test tubes without coagulant. Whole blood for hematological analysis was sampled from the external jugular vein into $2 \mathrm{ml}$ test tubes containing $\mathrm{K}_{2}$ EDTA. The results of the research indicate significant morphological differences of white blood cells line and red blood cells line of fallow deer in comparison to other ruminants. Proerythroblasts of fallow deer appear to have a higher number of nuclei that stain more clearly in the MGG method. In red the blood cells line a high percentage of polychromatic erythroblasts $(17.2 \%)$ and basophilic erythroblasts $(8.19 \%)$ was noted. In granulocyte line only $0.97 \%$ of myeloblasts was observed in bone marrow smears. The percentage of segmented and band granulocytes was determined at $\mathbf{6 . 8 6 \%}$ and $\mathbf{2 . 2 7 \%}$ consequently. In the lymphoblastic line of fallow deer a low percentage of plazmocytes was observed $(1.16 \%)$. In the platelets line the percentage of megakaryoblasts $(5.85 \%)$ was lower

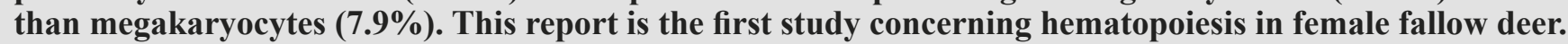

Keywords: fallow deer, bone marrow, erythropoiesis, granulopoiesis

Cells that give rise to morphotic components of peripheral blood are produced in a complex process of hematopoiesis (13). The stages of hematopoiesis are identical in fallow deer and other animals, including ruminants. During this process, colony-forming progenitor cells (CFU) develop from pluripotent stem cells. The erythroblast cell line is composed of basophilic, neutrophilic and acidophilic erythroblasts. Reticulocytes containing residual RNA are the next stage of cell maturation. Granulocytes and monocytes derive from the same colony forming unit (CFU-GM) which gives rise to granulocyte colonies (CFU-G) which develop to neutrophils and macrophage colonies (CFU-M) (12). Eosinophils derive from CFU-Eos progenitor cells, and basophils develop from CFU-Baso cells (22). Bone marrow analyses are very rarely conducted in free-living ruminants. The analyses that need to be carried out in order to qualify an animal for bone marrow collection are biochemical tests that rule out hematopoiesis occurring outside the bone marrow. In fallow deer and other animal species, we can distinguish yellow marrow, which is located primarily in long bones and consists mostly of fat cells, and red marrow (hematopoietic), located in cancellous bones (cranial bones, sternum, clavicle, ribs, vertebrae and pelvis).

The aim of this study was cytological evaluation of bone marrow smears of nonpregnant female fallow deer (Dama dama) from Pilsko-Lithuanian line kept in captivity. Animals derived from this line are slightly smaller than animals from Hungarian and Slovak lines but they have greater resistance to disease. The animals were kept on pastures all year where livestock density was 10 heads per hectare. In the spring, the summer, 
and the early autumn forage consists mainly of good quality grass and hay and salt licks. In the winter and the autumn the animals were fed hay and haylage $a d$ libitum. Sheds protecting animals from wind and rain were located on the pastures. Bone marrow evaluations in this species have never been documented in the literature worldwide. Due to that fact this experiment was undertaken to fill the knowledge gap. It is worth emphasizing that this is the first ever study to analyze the bone marrow of female fallow deer kept in captivity in Poland.

\section{Material and methods}

All experimental procedures followed the principles of animal care and were approved by the Local Ethics Commission for Animal Experiments (61/2011).

Bone marrow smears from 10 nonpregnant female fallow deer were stained according to the May-Grünwald Giemsa (MGG) method. Bone marrow samples of approximately $1 \mathrm{ml}$ were collected with a $63 \mathrm{~mm}, 13 \mathrm{G}$ biopsy needle from the $3^{\text {rd }}-4^{\text {th }}$ rib in the sternal region. The biopsy site was prepared in accordance with standard surgical procedures. Bone marrow was collected into $1 \mathrm{ml}$ test tubes without anticoagulant. Due to rapid clotting of the analyzed material, smears were performed immediately after collection on labeled slides. Whole blood for hematological analysis was sampled from the external jugular vein into $2 \mathrm{ml}$ test tubes containing $\mathrm{K}_{2}$ EDTA.

Bone marrow and peripheral blood smears were stained according to the MGG method. Staining time was $80 \mathrm{sec}-$ onds for the May-Grünwald solution and 5 minutes for the Giemsa solution. Staining time for peripheral blood smears was 3 minutes and 12 minutes, respectively. The Giemsa stain was diluted $1: 10$ with a phosphate buffer with $\mathrm{pH}$ 7.2. The morphological parameters of peripheral blood were determined in the ADVIA 2120i hematology analyzer. The following hematological parameters were determined: white blood cell (WBC) counts, hemoglobin $(\mathrm{Hb})$ concentration, red blood cell (RBC) counts, hematocrit (HCT) levels, platelet (PLT) counts, mean corpuscular volume (MCV), mean corpuscular hemoglobin $(\mathrm{MCH})$, mean corpuscular hemoglobin concentration (MCHC), red blood cell distribution width (RDW) and mean platelet volume (MPV). Bone marrow cells were counted in the SH-96/24D cell counter. 1000 cells were counted on bone marrow stained smears. Peripheral blood smears were performed to rule out any red blood cells and white blood cells pathologies. Fallow deer were captured with nets and sedated with $1.5 \mathrm{mg} / \mathrm{kg}$ xylazine hydrochloride (Rompun Bayer, Leverkusen, Germany) and $2.2 \mathrm{mg} / \mathrm{kg}$ zolazepam and tiletamine (Zoletil, Virbac, France).

\section{Results and discussion}

The results for each cell line are presented in tabular form. Smears of peripheral blood made with $\mathrm{K}_{2}$ EDTA were also analyzed in this study.

The percentage distribution of granulocytes in all stages of maturation in each of the animals is presented in Tab. 1. Myeloblasts are the first morphologically distinct granulocytes. Myeloblasts are round, and they have clearly stained, densely packed, dark blue nuclei. The percentages of granulocytes representing successive stages of maturation - promyelocytes, metamyelocytes, myelocytes and band cells - were relatively low. The percentage of segmented granulocytes was determined at $6.86 \%$, and those cells were the largest group in the granulocytic cell line.

The percentage distribution of erythroblasts in the bone marrow of fallow deer is presented in Tab. 2 . The first morphologically distinct cell in this line is

Tab. 1. Percentage distributions of granulocytes in evaluations of bone marrow sampled from deer

\begin{tabular}{|c|c|c|c|c|c|c|c|c|c|c|c|c|c|c|}
\hline $\begin{array}{c}\text { No. of } \\
\text { animal }\end{array}$ & $\begin{array}{c}\text { MBL } \\
\%\end{array}$ & $\begin{array}{c}\text { PML } \\
\%\end{array}$ & $\begin{array}{c}\text { MYE } \\
\%\end{array}$ & $\begin{array}{c}\text { MET } \\
\% \\
\end{array}$ & $\begin{array}{c}\text { BAND } \\
\% \\
\end{array}$ & $\begin{array}{c}\text { SEG } \\
\%\end{array}$ & $\begin{array}{c}\text { EMYE } \\
\% \\
\end{array}$ & $\begin{array}{c}\text { EMET } \\
\%\end{array}$ & $\begin{array}{c}\text { EBAND } \\
\%\end{array}$ & $\begin{array}{c}\text { EOS } \\
\%\end{array}$ & $\begin{array}{c}\text { BMYE } \\
\%\end{array}$ & $\begin{array}{c}\text { BMET } \\
\%\end{array}$ & $\begin{array}{c}\text { BBAND } \\
\%\end{array}$ & $\begin{array}{c}\text { BAS } \\
\% \\
\end{array}$ \\
\hline 1 & 0.2 & 0.3 & 1.0 & 2.5 & 3.1 & 6.8 & 0.9 & 2.0 & 2 & 3.1 & 0 & 0 & 0 & 0.5 \\
\hline 2 & 0.1 & 0.4 & 0.8 & 2.1 & 2.2 & 8.7 & 0.8 & 1.5 & 1 & 3.6 & 0 & 0 & 0.1 & 1.0 \\
\hline 3 & 0.1 & 0.4 & 0.7 & 2.0 & 2.3 & 8.0 & 0.9 & 1.5 & 3 & 1.8 & 0.1 & 0 & 0.2 & 1.0 \\
\hline 4 & 0.1 & 0.6 & 1.0 & 1.8 & 2.4 & 7.9 & 1.1 & 2.0 & 2 & 3.2 & 0 & 0.2 & 0.1 & 0.5 \\
\hline 5 & 0.2 & 0.5 & 0.6 & 1.9 & 2.6 & 8.1 & 1.3 & 1.5 & 2 & 5 & 0.1 & 0.1 & 0.1 & 0.5 \\
\hline 6 & 0.3 & 0.9 & 1.1 & 2.1 & 1.4 & 6.5 & 0.5 & 1.0 & 1 & 5.7 & 0 & 0 & 0 & 0.3 \\
\hline 7 & 0.1 & 0.7 & 1.1 & 2.5 & 2.6 & 6.8 & 0.8 & 1.0 & 2 & 3.8 & 0.1 & 0.2 & 0.6 & 0.5 \\
\hline 8 & 0.4 & 0.5 & 1.2 & 2.4 & 2.9 & 7.2 & 0.3 & 2.0 & 3 & 4.7 & 0 & 0.1 & 0.3 & 0.4 \\
\hline 9 & 0.2 & 0.6 & 1.1 & 2.3 & 1.2 & 4.1 & 0.4 & 2.5 & 1 & 4.2 & 0.4 & 0.9 & 0.3 & 1.0 \\
\hline 10 & 0.1 & 0.3 & 1.1 & 1.9 & 2.0 & 4.5 & 0.5 & 1.3 & 1 & 4.1 & 0.7 & 0.3 & 0.3 & 0.5 \\
\hline SD & 0.10 & 0.19 & 0.20 & 0.26 & 0.61 & 1.52 & 0.32 & 0.49 & 0.79 & 1.10 & 0.23 & 0.27 & 0.18 & 0.27 \\
\hline Mean & 0.18 & 0.52 & 0.97 & 2.15 & 2.27 & 6.86 & 0.75 & 1.63 & 1.8 & 3.92 & 0.14 & 0.18 & 0.2 & 0.6 \\
\hline
\end{tabular}

Explanations: MBL - myeloblast; PML - promyelocyte; MYE - neutrophilic myelocyte; MET - neutrophilic metamyelocyte; BAND - band neutrophil; SEG - neutrophilic granulocyte; EMYE - eosinophilic myelocyte; EMET - eosinophilic metamyelocyte; EBAND - band eosinophil; EOS - eosinophilic granulocyte; BMYE - basophilic myelocyte; BMET - basophilic metamyelocyte; BBAND - band basophile; BAS - basophilic granulocyte 


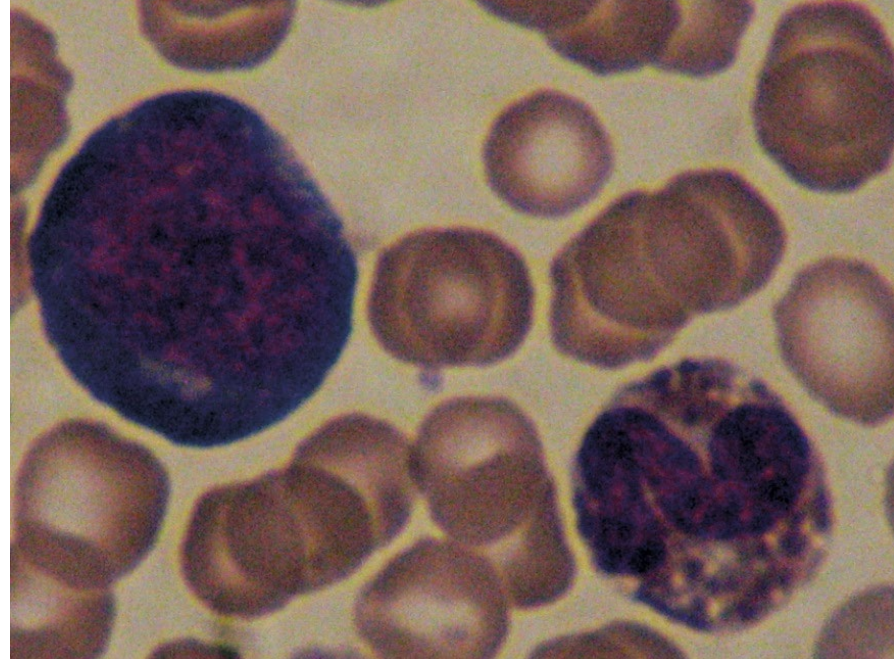

Fig. 1. Proerythroblast in bone marrow smears

the proerythroblast with a large and well-stained dark blue nucleus surrounded by blue cytoplasm (Fig. 1,2). The nucleus shrinks and the cytoplasm turns reddish in successive stages of cell maturation. Polychromatic erythroblasts were the largest group of cells that accounted for $17.2 \%$ of the erythroblastic cell line.

The percentage distribution of monocytes and macrophages is shown in Tab. 3. Monocytes were the predominant group of cells in the evaluated smears $(2.48 \%)$.

The percentage distribution of the lymphoid cell line is presented in Tab. 4. Lymphocytes were the largest population of lymphoid cells, accounting for $12.22 \%$ of the evaluated cell line.

The largest cell group in the thrombocytic line (Tab. 5) were the megakaryocytes which accounted for $7.9 \%$ of the platelet population. Megakaryocytes

Tab. 2. Percentage distributions of erythrocytes in evaluations of bone marrow sampled from deer

\begin{tabular}{|c|c|c|c|c|}
\hline $\begin{array}{c}\text { No. of } \\
\text { animal }\end{array}$ & $\begin{array}{c}\text { PROERBL } \\
\%\end{array}$ & $\begin{array}{c}\text { BASO ERBL } \\
\%\end{array}$ & $\begin{array}{c}\text { POLY ERBL } \\
\%\end{array}$ & $\begin{array}{c}\text { ORTO ERBL } \\
\%\end{array}$ \\
\hline 1 & 5.2 & 9.5 & 13.9 & 16.0 \\
\hline 2 & 4.3 & 5.9 & 15.1 & 8.9 \\
\hline 3 & 6.1 & 5.8 & 15.8 & 10.5 \\
\hline 4 & 4.4 & 9.1 & 16.8 & 9.8 \\
\hline 6 & 4.2 & 6.4 & 15.2 & 8.7 \\
\hline 7 & 6.1 & 9.3 & 20.9 & 9.1 \\
\hline 8 & 7.8 & 9.4 & 23.0 & 7.8 \\
\hline 10 & 5.3 & 8.1 & 16.9 & 8.2 \\
\hline SD & 4.9 & 8.3 & 15.6 & 8.4 \\
Mean & 5.3 & 10.1 & 18.8 & 6.3 \\
\hline
\end{tabular}

Explanations: PROERBL - proerythroblast; BASO ERBL - basophilic erythroblast; POLY ERBL - polychromatic erythroblast; ORTO ERBL - orthochromatic erythroblast

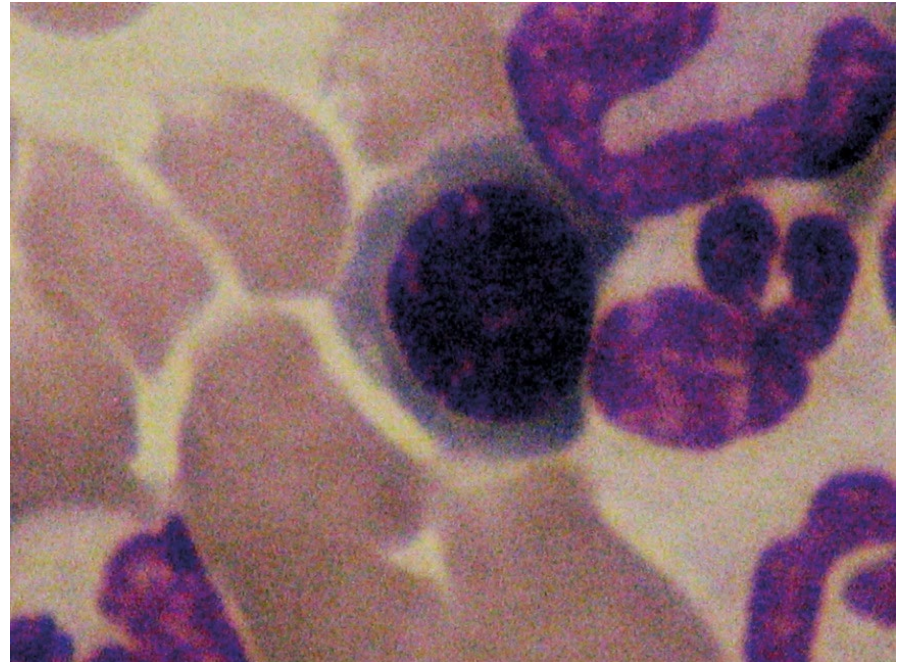

Fig. 2. Orthochromatic erythroblast in bone marrow smears

are the largest cells in thrombocyte and lymphoid line. Their cytoplasm is fairly pink with small fragments shedding at the edges.

The results of morphological evaluations confirmed the high percentage of neutrophils and lymphocytes in the analyzed samples of peripheral blood, which is consistent with the WBC counts in bone marrow smears presented in Tab. 6 .

The percentage distribution of all the cell lines of bone marrow is shown in Tab. 7. All recognized cells from all cell lines constitute $98.19 \%$ and the remaining $1.19 \%$ represent the unidentified cells.

Laboratory analyses play a very important role in evaluating the health of free-living ruminants and their populations. According to our best knowledge, this is the first ever study documenting the results of bone marrow smears of female fallow deer. Barić et al. (2)

Tab. 3. Percentage distributions of monocyte cells in evaluations of bone marrow sampled from deer

\begin{tabular}{|c|c|c|c|}
\hline No. of animal & $\begin{array}{c}\text { MNBL } \\
\%\end{array}$ & $\begin{array}{c}\text { PROMN } \\
\%\end{array}$ & $\begin{array}{c}\text { MON } \\
\%\end{array}$ \\
\hline 1 & 0.9 & 0.3 & 2.2 \\
2 & 0.4 & 0.7 & 2.5 \\
3 & 0.3 & 0.4 & 2.1 \\
\hline 4 & 1.0 & 0.3 & 3.1 \\
\hline 5 & 1.0 & 0.2 & 1.8 \\
\hline 7 & 1.0 & 0.3 & 2.3 \\
8 & 0.3 & 0.1 & 2.4 \\
\hline 9 & 0.9 & 0.2 & 2.8 \\
\hline 10 & 0.6 & 0.3 & 2.7 \\
\hline SD & 1.0 & 0.1 & 2.9 \\
Mean & 0.31 & 0.17 & 0.40 \\
\hline
\end{tabular}

Explanations: MNBL - monoblast; PROMN - promonocyte; MON - monocyte 
Tab. 4. Percentage distributions of lymphoid cells in evaluations of bone marrow sampled from deer

\begin{tabular}{|c|c|c|c|c|c|c|}
\hline $\begin{array}{l}\text { No. of } \\
\text { animal }\end{array}$ & $\begin{array}{c}\text { LBL } \\
\%\end{array}$ & $\begin{array}{c}\text { PLYM } \\
\%\end{array}$ & $\begin{array}{c}\text { LYM } \\
\%\end{array}$ & $\begin{array}{c}\text { PLBL } \\
\%\end{array}$ & $\begin{array}{l}\text { PLAZ } \\
\%\end{array}$ & $\begin{array}{l}\text { LC } \\
\%\end{array}$ \\
\hline 1 & 0.8 & 2.2 & 11.3 & 0.2 & 0.3 & 0.1 \\
\hline 2 & 2.2 & 4.5 & 9.6 & 0.3 & 0.4 & 0.1 \\
\hline 3 & 2.2 & 3.3 & 10.8 & 0.1 & 0.8 & 0.1 \\
\hline 4 & 1.1 & 3.0 & 16.8 & 0.3 & 0.4 & 0.03 \\
\hline 5 & 1.2 & 3.5 & 11.8 & 0.5 & 0.2 & 0 \\
\hline 6 & 1.1 & 2.5 & 14.9 & 0.4 & 0.9 & 0.1 \\
\hline 7 & 2.2 & 3.2 & 11.2 & 0.2 & 1.1 & 0.1 \\
\hline 8 & 1.2 & 3.8 & 11.1 & 0.4 & 3.2 & 0 \\
\hline 9 & 1.1 & 4.2 & 14.3 & 0.5 & 1.8 & 0.1 \\
\hline 10 & 1.1 & 4.3 & 10.4 & 0.2 & 2.5 & 0.1 \\
\hline SD & 0.55 & 0.76 & 2.31 & 0.14 & 1.02 & 0.044 \\
\hline Mean & 1.42 & 3.45 & 12.22 & 0.31 & 1.16 & 0.073 \\
\hline
\end{tabular}

Explanations: LBL - lymphoblast; PLYM - prolymphocyte; LYM - lymphocyte; PLBL - plasmocytoblast; LC - lymphoid cells

demonstrated differences in the average values of RBC counts, RBC parameters and WBC counts in freeliving ruminants. In the present study, similar results were noted in peripheral blood samples collected from female fallow deer. Marco and Lavin (10) reported a relationship between the method of collecting peripheral blood samples and the results of hematological and biochemical analyses. They demonstrated significant differences in $\mathrm{RBC}$ counts, $\mathrm{Hb}$ concentrations, the counts of segmented neutrophils, lymphocytes and monocytes in animals with and without using anesthetics. The authors attributed the observed changes to the animals' response to the stress, even short-lived stress, during capture. Similar changes in hemogram parameters were noted in this study, which suggests that leukograms of both red deer and fallow deer are rapidly affected by stress that results in an increase in number of segmental granulocytes. Janicki et al. (7) demonstrated that even short-lived stress influences the number of cells in peripheral blood. Ban et al. (1) observed in a study conducted on cattle that the nuclei of basophilic erythroblasts were shifted to the edge of the cytoplasm, whereas in fallow deer, the nucleus was positioned in the center of the erythroblast. Rosef et al. (15) did not report differences in hematological parameters across age groups and their results were similar to our findings. The percentage of monocytes, lymphocytes and neutrophils noted by English and Lepherd (4) in peripheral blood smears was similar to that noted in this study. The bone marrow of fallow deer was very difficult to evaluate due to the absence of publications containing reference data. For this reason, our results were compared with the bone marrow parameters reported in ruminants. Hoedemaker et al. (6) described the role and functions of polymorphonuclear neutrophils and emphasized their complex
Tab. 5. Percentage distributions of platelet producing cells in evaluations of bone marrow sampled from deer.

\begin{tabular}{|c|c|c|}
\hline No. of animal & MGBL\% & MEG\% \\
\hline 1 & 7 & 9 \\
2 & 5 & 10 \\
3 & 8 & 7 \\
4 & 7 & 9 \\
5 & 6.5 & 9 \\
6 & 4 & 10 \\
7 & 4 & 8 \\
8 & 4 & 4 \\
9 & 6 & 7 \\
10 & 7 & 6 \\
SD & 1.49 & 1.91 \\
Mean & 5.85 & 7.9 \\
\hline
\end{tabular}

Explanations: MGBL - megakaryoblast; MEG - megakaryocyte

Tab. 6. Hematologic parameters of peripheral blood

\begin{tabular}{|l|c|c|}
\hline \multicolumn{1}{|c|}{ Parameter } & Mean & SD \pm \\
\hline RBC $\left(\times 10^{12} / l\right)$ & $12.4 \pm 1.12$ & $10-13.8$ \\
\hline HGB $(\mathrm{g} / \mathrm{l})$ & $191 \pm 18.9$ & $154-230$ \\
\hline MCH $(\mathrm{pg})$ & $15.7 \pm 0.63$ & $14.2-16.5$ \\
\hline MCV (fl) & $45.2 \pm 2.49$ & $41-55$ \\
\hline MCHC $(\mathrm{g} / \mathrm{l})$ & $347 \pm 14.41$ & $317-366$ \\
\hline RDW $(\%)$ & $20.1 \pm 0.94$ & $18.5-21.3$ \\
\hline WBC $\left(\times 10^{9} / \mathrm{l}\right)$ & $13.48 \pm 0.9$ & $43-53.8$ \\
\hline Neutrophils $\left(\times 10^{9} / \mathrm{l}\right)$ & $3.6 \pm 0.09(78-87 \%)$ & $57-94$ \\
\hline Lymphocytes $\left(\times 10^{9} / \mathrm{l}\right)$ & $0.79 \pm 0.15(21-45 \%)$ & $3-35$ \\
\hline Eosinophiles $\left(\times 10^{9} / \mathrm{l}\right)$ & $0.02 \pm 0.03(0-5 \%)$ & $0-3$ \\
\hline Monocytes $\left(\times 10^{9} / \mathrm{l}\right)$ & $0.65 \pm 0.67(0-4 \%)$ & $0-6$ \\
\hline Platelets $\left(\times 10^{9} / \mathrm{l}\right)$ & $254 \pm 1044(2-35 \%)$ & $32-367$ \\
\hline
\end{tabular}

Tab. 7. Percentage distribution of all bone marrow cell lines

\begin{tabular}{|l|r|}
\hline Granulocytes & $22.17 \%$ \\
Erythrocytes & $40.12 \%$ \\
\hline Monocyte cells & $3.51 \%$ \\
Lymphoid cells & $18.63 \%$ \\
\hline Platelets & $13.75 \%$ \\
Unidentified cells & $1.81 \%$ \\
\hline
\end{tabular}

structure in cattle. In the work of Snarska et al. (18), the percentage of proerythroblasts (PROERBL) in healthy Holstein-Friesian cattle was determined at $2.3 \%$ which was higher than in fallow deer. In fallow deer, polychromatic erythroblasts (POLYERBL) were the largest group that accounted for $17.2 \%$ of the erythroblastic cell line. In fallow deer and in healthy cattle, neutrophil granulocytes with segmented nuclei (SEG) were the largest group $(6.86 \%)$ of the granulocytic cell line. According to Snarska et al. (17), the smallest granulocyte groups were basophilic myelocytes (BMYE) and 
basophilic granulocytes (BAS). Similar results were noted in the present study evaluating the bone marrow smears of female fallow deer. The study of Burvenich et al. (3), who investigated WBC counts and activity, demonstrated that bone marrow responds rapidly to infection by releasing immature granulocytes - myelocytes and metamyelocytes - into the bloodstream in peripheral blood smears during inflammation in cattle. Similar observations were made by Heynemann et al. (5). Steffen et al. (21) evaluated the bone marrow of cattle with genetic disorders and reported abnormal counts of bone marrow cells. Studies evaluating bone marrow in cattle clearly indicate that granulocytes play a highly significant role in inflammations and bone marrow responses to hormonal regulation (11), which is also manifested in the morphology of manual peripheral blood smears. Merris et al. (14) observed significant abnormalities in WBC counts during pregnancy. Lin and Linzer (9) reported correlations between megakaryocyte counts and the activity of thrombopoietin and cytokines during pregnancy and shortly after parturition. McCrae (12) demonstrated a drop in megakaryocyte counts during pregnancy, which was associated with a decrease in megakaryocyte counts in the bone marrow. Those changes led to a decrease in platelet counts in peripheral blood. According to Snarska and Sobiech (20) significant differences in numbers and percentage of all cell lines in pregnant and nonpregnant fallow deer were noticed. Keller et al. (8) investigated cattle infected with BVDV and noted a significant decrease in myelocyte and metamyelocyte counts in the bone marrow, which affected granulocyte counts in morphological analyses. Scruggs et al. (16) demonstrated that BVD/MD infections decrease the populations of erythroblasts in all stages of maturation and provoke a drop in the counts of neutrophilic metamyelocytes and acidophilic myelocytes. Similar results were reported by Snarska et al. (19).

The cited results and published data suggest that hematological parameters can be a robust indicator of abnormalities in the bone marrow and in hematopoiesis processes already during early stages of cell division and maturation. In this study, bone marrow samples from healthy animals were evaluated together with the morphological parameters of peripheral blood. This is the first ever study to analyze bone marrow cells in fallow deer and our results could constitute a basic frame of reference for future investigations into hematopoietic processes in fallow deer and other ruminants. There is a general scarcity of relevant data in the literature and further research is needed to explore this crucial determinant of health in free-living ruminants.

In conclusion, the cytological evaluation of bone marrow smears in addition to the hematological analyses provides a great deal of relevant information on the process of hematopoiesis. The articles cited and authors' own research indicate that in the evaluation of pathological processes (including inflammation process) and physiological ones (pregnancy), changes in morphological parameters of blood are reflected during the processes of hematopoiesis occurring in bone marrow.

\section{References}

1. Ban A., Ogata Y., Kato T.: Erythrocyte morphology and frequency of spherocytes in hereditary erythrocyte membrane protein disorder in Japanese Black cattle. Bull. Nippon Vet. Anim. Sci. Univ. 1995, 44, 21-27.

2. Barić R. R., Tonćić R. J., Vicković I., Sostarić B.: Haematological and biochemical values of farmed red deer. Vet. Arhiv 2011, 81, 513-523.

3. Burvenich C., Paape M. J., Hill A. W., Guidry A. J., Miller R. H., Heyneman R., Kremer W. D. J.: Role of neutrofil leucocyte in the local and systemic reactions during experimentally induced E. coli mastitis in cows immediately after calving. Vet. Quart. 1994, 16, 45-50.

4. English A. W., Lepherd E. E.: The haemathology and serum biochemistry of wild fallow deer (Dama dama) in New South Wales. J. Wildlife Dis. 1991, $17,289-395$.

5. Heynemann R., Burvenich C., Vecauteren R.: Interaction between the respiratory burst activity of neutrophil leukocytes and experimentally induced Escherichia coli mastitis in cows. J. Dairy Sci. 1990, 73, 985-994.

6. Hoedemaker M., Lund L. A., Wagner W. C.: Influence of arachidonic-acid metabolites and steroids on function of bovine polymorphonuclear neutrophils. Vet. Res. 1992, 53, 1534-1539.

7. Janicki Z., Forsek J., Slavica A., Kolić E., Dezdek D., Manojlović L.: Haematological values of fallow deer (Dama dama) population in continental and island habitats of Croatia. Vet. Arhiv 2000, 70 (Suppl.), 201-206.

8. Keller S. L., Jefferson B. J., Jacobs R. M., Wood D.: Effect of noncytopathic type 2 Bovine viral diarrhea virus on the proliferation of bone marrow progenitor cells. Can. J. Vet. Res. 2000, 70, 20-27.

9. Lin J., Linzer D. I.: Induction of megakaryocyte differentiation by a novel pregnancy-specific hormone. J. Biol. Chem. 1999, 274, 21485-21489.

10. Marco I., Lavin S.: Effect of the method of capture on the haemathology and chemistry of red deer (Cervus elaphus). Res. Vet. Sci. 1999, 66, 81-84

11. Maryuama S., Minagawa M., Shimizu T., Oya H., Yamamoto S., Musha N., Abo W., Weerasinghe A., Hatakeyama K., Abo T.: Administration of glucocorticosteroids markedly increases the numbers of granulocytes and extrathymic T cells in the bone marrow. Cell. Imunol. 1999, 194, 28-35.

12. McCrae K. R.: Thrombocytopenia in pregnancy: differential diagnosis, pathogenesis, and management. Blood Rev. 2003, 17, 7-14.

13. Merris V., Meyer E., Duchateau L., Burvenich C.: Differential effects of steroid and retinoid on bovine myelopoiesis in vitro. J. Dairy Sci. 2004, 87, 1188-1195.

14. Merris V., Van Meyer E., Dosogne H., Burvenich C.: Separation of bovine bone marrow into maturation-related cell fractions. Vet. Immunol. Immunopathol. 2001, 83, 11-17.

15. Rosef O., Nystoyl H., Solenes T., Arnemo J. M.: Haematological and serum biochemical reference values in free ranging red deer (Cervus elaphus atlanticus). Rangifer 2004, 24, 79-85.

16. Scruggs D. W., Fleming S. A., Maslin W. R., Groce A. W.: Osteopetrosis, anemia, thrombocytopenia, and marrow necrosis in beef-calves naturally infected with Bovine Virus Diarrhea Virus. J. Vet. Diagn. Invest. 1995, 7, 555-559.

17. Snarska A., Krystkiewicz W., Rękawek W.: Assesment of leukocytes in the bone marrow of healthy Holstein- Friesian cows. Med. Weter. 2013, 69, 674-677.

18. Snarska A., Krystkiewicz W., Sobiech P., Żarczyńska K., Rękawek W., Stopyra A.: Assesment of erythroblastic cells in the bone marrow of healthy Holstein- Friesian cows. Med. Weter. 2013, 69, 540-542.

19. Snarska A., Krystkiewicz W., Żarczyńska K., Ręawek W., Sobiech P., Radwińska J.: Evaluation of bone marrow in Holstein-Fresian cattle infected with the BVDV virus. Med. Weter. 2013, 69, 187-190.

20. Snarska A., Sobiech P.: Evaluation of bone marrow with particular consideration of the megakaryocyte lineage and coagulation profile in pregnant fallow deer (Dama dama). Pol. J. Vet. Sci. 2016, 19:359-364. DOI: 10.1515 pjvs-2016-0044

21. Steffen D. J., Elliott G., Leipold H. W., Smith J. E.: Congenital dyserythtropoesis and progressive alopecia in Polled Hereford calves: hematologic, biochemical, bone marrow cytologic, electrophoretic, and flow cytometric findings. J. Vet. Diagn. Invest. 1992, 4, 31-37.

22. Wardlaw A. J., Kay A. B.: Eosinophils: production, biochemistry and function. Williams Hematology, New York 1995, 798-805

Corresponding author: Dr hab. Przemyslaw Sobiech, Prof. UWM, ul. Oczapowskiego 14, 10-957 Olsztyn, Poland; e-mail: psobiech@uwm.edu.pl 